Tersedia online di: http://ejournal-balitbang.kkp.go.id/index.php/jra

\title{
RESPONS IMUNITAS BENIH LOBSTER, Panulirus homarus DENGAN PENGGUNAAN PROBIOTIK PADA PAKAN MOIST
}

\author{
Haryanti*), Sari Budi Moria Sembiring*), Sudewi*, Zeny Widiastuti*, \\ Nyoman Adiasmara Giri*), dan Ketut Sugama*)
}

Balai Besar Riset Budidaya Laut dan Penyuluhan Perikanan

(Naskah diterima: 21 November 2016; Revisi final: 10 Maret 2017; Disetujui publikasi: 20 Maret 2017)

\begin{abstract}
ABSTRAK
Pemeliharaan benih lobster P. homarus masih menghadapi beberapa permasalahan, di antaranya infeksi penyakit bakteri (red body disease) dan mortalitas yang tinggi. Tujuan penelitian ini adalah untuk mengkaji respons imunitas benih lobster P. homarus yang diberi pakan pelet basah (moist diets) dengan penambahan probiotik. Pemeliharaan benih lobster dilakukan secara individu (1 ekor/keranjang). Lama pemeliharaan selama tiga bulan. Bobot awal puerulus P. homarus adalah 0,37 $\pm 0,05 \mathrm{~g}$. Perlakuan meliputi pemberian pakan moist yang ditambahkan (A) ragi Saccharomyces cerevisiae, (B) kombinasi probiotik, Alteromonas sp. BY9 dan Bacillus cereus BC, dan (C) tanpa probiotik. Respons imunitas dianalisis dengan RT-qPCR melalui tujuh gen target terkait ekspresi imunitas, setelah diuji tantang dengan Vibrio harveyi (penyebab red body disease). Hasil penelitian menunjukkan bahwa sintasan benih lobster sebesar (A) $32,22 \%$ (B) $29,63 \%$ dan (C) $33,33 \%$ Pertumbuhan panjang dan bobot benih lobster tidak berbeda nyata $(P>0,05)$. Respons imunitas benih lobster P. homarus pada perlakuan A dan B menunjukkan nilai ekspresi imun yang lebih tinggi dibandingkan dengan perlakuan C (tanpa probiotik). Ekspresi gen penyandi anti lipopolisakarida (ALFHa-1) meningkat pada (A) rata-rata sebesar 3,44 kali dan (B) 3,25 kali dibandingkan dengan perlakuan C (2,43 kali). Kelipatan ekspresi profenoloksidase (proPO) benih lobster meningkat pada perlakuan A (penambahan ragi) rata-rata sebesar 5,27 kali, sedangkan pada perlakuan B (kombinasi probiotik) sebesar 12,92 kali. Ekspresi Clotting sistem (transglutaminase, clotting protein) dan antioxidant defense mechanism (glutathione peroxidase/GPO) dan SAA juga mengalami peningkatan pada perlakuan A dan B.
\end{abstract}

KATA KUNCl: benih lobster; Panulirus homarus; probiotik; ekspresi terkait imunitas

ABSTRACT: Immunity response of juvenile spiny lobster, Panulirus homarus with probiotic supplementation on moist diets. By: Haryanti, Sari Budi Moria Sembiring, Sudewi, Zeny Widiastuti, Nyoman Adiasmara Giri, and Ketut Sugama

A number of contrainsincluding disease infections and significant mortality have been occurring in lobster aquaculture. The aim of this research was to observe the immune response of juvenile lobster P. homarus culture fed by moist pellet supplemented with probiotic. Experimental juveniles werereared in individual system (onejuvenile/basket). The experiment was conducted for three months. The treatments comprised (A) whole cell of yeast Saccharomyces cerevisiae, (B) combination of probiotics Alteromonas sp. BY-9 and Bacillus sp. BC, and (C) without probiotic as control. Initial weight of juveniles were $0.37 \pm 0.05 \mathrm{~g}$. Immunity responses were analyzed using seven immunity related genes expression by RT-qPCR. The results showed that the survival rate of juvenile for treatments $A, B$, and $C$ were $32.22 \%$ $29.63 \%$ and $33.33 \%$ respectively. The weight and length gain of the juvenile were not significantly different $(P>0.05)$ among treatments. Based on immunity related gene expression analysis, it revealed that $A$ and $B$ treatmentshave shown differences in the increament of immunity responses. Expressions of ALFHa-1 genes were increased on (A) treatment with average of 3.44 fold and (B) treatment ( 3.25 fold) and higher than $C$ treatment $(2.03$ fold). Prophenoloxidase (ProPO) expression was increase average up to 5.27 fold on $\mathrm{A}$ (yeast supplementated) treatment and $\mathrm{B}$ (combination of probiotic) were 12.92 fold. Gene expression on Clotting system (transglutaminase, clotting protein) and antioxidant defense mechanism (glutathione peroxidase/GPO) was increased on A and B treatments.

KEYWORDS: puerulus; probiotics; Panulirus homarus; immunity - related gen expression

\footnotetext{
\# Korespondensi: Balai Besar Riset Budidaya Laut dan

Penyuluhan Perikanan. Jl. Br. Gondol, Kec. Gerokgak Kab.

Buleleng, Kotak Pos 140, Singaraja, Bali 81101, Indonesia.

Tel. + (0362) 92278

E-mail: haryanti@ indosat.net.id
} 


\section{PENDAHULUAN}

Lobster merupakan komoditas ekspor yang dieksploitasi dari penangkapan di laut. Hingga kini belum ada hatcheri di Indonesia yang berhasil memproduksi larva (puerulus) atau benih (post puerulus). Di samping meto de pembenihan yang belum dikuasai, juga diperlukan waktu yang panjang untuk memelihara larva (6-9 bulan) sehingga dirasakan tidak ekonomis. Tingginya permintaan ekspor benih lobster, menyebabkan penangkapan benih di alam dilakukan secara intensif.

Budidaya lobster dengan keramba jaring apung $(\mathrm{KJA})$ telah dilakukan di beberapa daerah di Indonesia: Lombok, Bima, Sape, Sulawesi Selatan, Sulawesi Tenggara, dan Aceh (Ujung Batee) dengan kontribusi sebesar 2,67\% (308 ton/tahun) dari total produksi budidaya (Priyambodo, 2014). Sementara, Vietnam merupakan negara dengan perkembangan budidaya lobster yang pesat sejak tahun 2005. Produksi tahunan lobster dihasilkan secara konsisten mencapai 1.500 ton dengan bobot 300-500 g/ekor (P. ornatus) (Anh \& Jones, 2014).

Tingkat keberhasilan pemeliharaan lobster di Indonesia masih rendah, terutama pemeliharaan pada tingkat puerulus hingga menjadi juvenil dengan sintasan hanya sekitar 20\%50\%(Shanks et al., 2014). Hal yang sama juga dialami dalam pemeliharaan dari juvenil hingga ukuran konsumsi. Lobster P. homarus yang dipelihara dari ukuran juvenil $2 \mathrm{~cm}$ hingga $200 \mathrm{~g}$ selama enam bulan, hanya diperoleh sintasan $<50 \%$ Namun, pembudidaya lobster P. ornatus di Vietnam selama delapan bulan pemeliharaan dari juvenil $2 \mathrm{~cm}$ hingga $350 \mathrm{~g}$ dapat memperoleh sintasan hingga $90 \%$ bila sistem pemeliharaan dan nutrisinya baik (Priyambodo \& Sarifin, 2009; Anh \& Jones, 2014). Mortalitas yang masih tinggi tersebut disebabkan oleh sifat kanibalisme atau infeksi penyakit, stres transportasi, kualitas air, dan manajemen pemeliharaan yang belum standar. Beberapa penyakit pada spiny lobster di antaranya adalah milky hemolymph disease (Anonymous, 2007, Nunan et al., 2010), red body disease, black gill disease, red tail disease (Sields, 2011), dan WSSV (White Spot Syndrome Virus) (Clark et al., 2013). Beberapa penelitian telah dilakukan untuk mencegah terjadinya infeksi penyakit, di antaranya dengan perbaikan mutu lingkungan dan penyediaan pakan dengan formulasi yang memadai. Hasil penelitian pengaruh parameter lingkungan dan lama penampungan terhadap respons imun pada P. homarus dan P. cygnus menunjukkan bahwa perubahan ekstrem lingkungan dan efek penampungan (empat hari) dapat menginduksi perubahan imunitas lobster (Verghese et al., 2007).
Informasi tentang penambahan dan penggunaan imunostimulan pada pemeliharaan benih lobster dalam budidaya masih terbatas. Komponen yang sering digunakan pada upaya peningkatan kesehatan dan pencegahan penyakit pada krustasea adalah imunostimulan ( $\beta$-glucan). Kemampuan imunostimulan dalam meningkatkan respons kekebalan tubuh nonspesifik memperlihatkan hasil positif pada krustasea. Kerentanan terhadap infeksi mikroba sangat berhubungan dengan immuno kompetensi dan kemampuan untuk menolak mikroorganisme tersebut (Hauton et al., 2013 , Jimenez-Vega et al., 2004).

Strategi untuk mengkontrol penyakit infeksi meliputi peningkatan kondisi lingkungan, penggunaan benih sehat, serta peningkatan daya tahan terhadap penyakit dengan menggunakan probiotik. Zokaeifar et al. (2012), Karla et al. (2011), dan Li et al. (2009), menyatakan bahwa penggunaan probiotik pada udang L. vannamei dapat meningkatkan performa pertumbuhan, enzim pencenakan, resistensi penyakit, immune gene expession, dan mengurangi prevalensi infeksi virus atau bakteri. Hasil uji tantang terhadap Vibrio fluvialis pada Homarus americanus menunjukkan nilai transkripsi respons protein antimikroba meningkat 17 kali (CIEark, 2013; Beale et al., 2009).

Efek protektif dan menguntungkan dari mikroba atau probiotik disinyalir dapat berperan sebagai imunostimulan, imunostimulator, suplemen pakan, dan bahan aditif. Manfaat mikroba atau probiotik sudah banyak dilaporkan antara lain untuk mencegah penyakit infeksi pada pemeliharaan krustasea dari stadia larva, juvenil hingga ukuran konsumsi, serta untuk menjaga kualitas air (Fu et al., 2011; Luis-Villasenor et al., 2011; Zhou et al., 2009; Balcazar et al., 2007; Rodriguez et al., 2007).

Oleh karena itu, pola ekspresi gen yang berhubungan dengan imunitas merupakan transcriptional respons terhadap infeksi penyakit. Pengaruh bahan suplemen (imunostimulan) akan berhubungan dengan sifat genotipe dan terekspresi pada sifat fenotipe, yaitu dengan menunjukkan kondisi sehat atau sakit.

Berdasarkan uraian di atas, penelitian yang berhubungan dengan respons imunitas lobster menjadi pilihan untuk mendapatkan benih yang sehat. Penelitian ini bertujuan untuk mendapatkan informasi tentang respons imunitas benih lobster P. homarus yang diberi pakan moist pelet dengan penambahan probiotik. Hasil penelitian ini diharapkan dapat digunakan untuk peningkatan produksi lobster melalui penyediaan benih lobster yang sehat pada perikanan budidaya yang dikembangkan di Indonesia. 


\section{BAHAN DAN METODE}

\section{Pemeliharaan Benih P. homarus}

Benih lobster diberi pakan moist pelet dengan perlakuan penambahan whole cell (A) ragi, S. cerevisiae; (B) kombinasi probiotik (Alteromonas sp. BY-9 dan Bacillus cereus $\mathrm{BC}$ ), dan (C) tanpa probiotik. Masing-masing bahan probiotik dicampurkan dalam pakan moist pelet. Ukuran rata-rata bobot benih yang digunakan adalah $0,37 \pm 0,05 \mathrm{~g}$ dan panjang total 2,34 $\pm 0,25 \mathrm{~cm}$. Pemeliharaan benih lobster dilakukan secara individu (1 ekor/keranjang), setiap perlakuan menggunakan satu set rangkaian keranjang (terdiri atas sembilan keranjang) dan diulang dua kali. Keranjang berbentuk bulat (diameter $20 \mathrm{~cm}$, tinggi $30 \mathrm{~cm}$ ) dan diapungkan dalam bak beton volume $5 \mathrm{~m}^{3}$. Setiap keranjang diberikan shelter berupa pipa PVC dan waring yang dibentuk seperti kipas untuk persembunyian benih lobster. Benih lobster dipelihara selama tiga bulan. Percobaan dengan rancangan acak lengkap dan dianalisis dengan ANOVA. Selama pemeliharaan dilakukan pembersihan sisa-sisa makanan, pergantian air dengan sistem mengalir. Pengamatan pertumbuhan panjang dan bobot, serta sintasan dilakukan setiap bulan, dan penghitungan hemosit dilakukan pada awal dan akhir pemeliharaan.

\section{Pembuatan Pakan Moist Pelet}

Persentase bahan baku untuk pembuatan pakan moist adalah tepung pelet udang $(24,77 \%$; tepung rebon $(24,77 \%)$; cumi dan udang segar masing masing $(24,77 \%)$; serta perekat (CMC) $(0,74 \%$; dan vitamin mix $(0,19 \%)$. Campuran tersebut ditambahkan mikroba ragi (100 mL, kepadatan $10^{11} \mathrm{sel} / \mathrm{mL}$ ), sedangkan untuk perlakuan kombinasi probiotik (Alteromonas sp. BY-9 dan Bacillus cereus BC), pakan moist ditambahkan probiotik tersebut masing-masing $50 \mathrm{~mL}$ dengan kepadatan $10^{12} \mathrm{sel} / \mathrm{mL}$ ). Setelah tercampur, bahan digiling untuk menghasilkan moist pelet. Hasil pakan moist tersebut selanjutnya dikeringanginkan selama tiga jam dan disimpan di dalam lemari pendingin pada suhu $5-6^{\circ} \mathrm{C}$. Pembuatan pakan moist dilakukan secara berkala untuk menghindari terjadinya penurunan nilai nutrisi. Komposisi proksimat pakan moist tertera pada Tabel 1.

\section{Penghitungan Hemosit}

Hemolim dikoleksi pada benih lobster dari ventral-sinus cavity menggunakan jarum 25 gauge dan syringe $1 \mathrm{~mL}$ yang berisi senyawa anticoagulant dingin $(2 \% \mathrm{NaCl} ; 0,1 \mathrm{M}$ glucose; $30 \mathrm{mM}$ Na citrat; $26 \mathrm{mM}$ asam citrat; 10mM EDTA). Pengambilan hemosit hanya dilakukan pada awal dan akhir perlakuan sebanyak tiga ekor setiap perlakuan. Penghitungan total hemosit dilakukan dengan mengambil hemolim $(10 \mu \mathrm{L})$ dan dihitung menggunakan hemositometer di bawah mikroskop cahaya dengan perbesaran 400x.

\section{Status Imunitas}

Pengamatan status imun dilakukan dengan membandingkan tingkat ekspresi mRNA pada hemosit benih lobster pada awal dan akhir perlakuan. Analisis ekspresi gen imunitas menggunakan RTq-PCR. Pengamatan respons imun dilakukan dengan uji tantang dengan V. harveyi penyebab red body disease secara kohabitasi. Uji tantang dilakukan selama 96 jam dengan interval waktu pengambilan hemolim setiap 24 jam.

\section{Ekspresi Gen Terkait Imunitas}

\section{Isolasi Total RNA dan Sintesis CDNA}

Hemolim yang telah dikoleksi, kemudian disentrifugasi dengan kecepatan $12.000 \mathrm{rpm}$ padasuhu $4^{\circ} \mathrm{C}$ selama 10 menit. Pelet hemosit yang diperoleh dicuci satu kali dengan larutan anticoagulant dingin dan disentrifugasi kembali dengan kecepatan yang sama. Selanjutnya dilakukan ekstraksi total RNA menggunakan laruran lysis RNA extraction dengan metode IQ-2000 yang telah dimodifikasi.

Sintesis cDNA (complementary DNA) dilakukan dengan menggunakan Agilent Affinity Script qPCR CDNA Synthesis kit. Volume reaksi $20 \mu \mathrm{L}$ yang terdiri atas $10,0 \mu \mathrm{L}$ first strand $2 \mathrm{x}$ master mix; 3,0 $\mu \mathrm{L}$ oligo (dT) primer; $1,0 \mu \mathrm{L}$ affinity script RT; dan 3,0 $\mu \mathrm{g}$ total RNA. Larutan dalam mikrotub diinkubasi berturut-turut pada suhu $25^{\circ} \mathrm{C}$ selama lima menit, $42^{\circ} \mathrm{C}$ (15 menit) dan $95^{\circ} \mathrm{C}$ selama lima menit. Larutan cDNA selanjutnya diletakkan dalam es untuk menghentikan reaksi sintesis dan disimpan pada suhu $-20^{\circ} \mathrm{C}$ untuk analisis berikutnya.

\section{Analisis RT-qPCR pada Gen yang Terkait dengan Imunitas $P$. homarus}

Analisis profil status imun menggunakan metode ekspresi transkripsi gen yang terkait dengan imunitas secara kuantitatif dengan RT-qPCR dan primer spesifik mengikuti Wang et al. (2010) dan Clark (2013). Analisis Pro PO, Glutathione Peroxidase (GPo), Clotting Protein dengan meto de Wang et al. (2010), sedangkan ALFHa1, ALFHa-2, SAA-Serum Amyloid Protein A mengikuti Clark (2013) seperti tertera pada Tabel 2. Internal kontrol menggunakan 18SrRNA. Analisis RT-qPCR dilakukan menggunakan ABI PRISM 7500 sistem deteksi sequens dengan $5 x$ Hot Firepol Evagreen qPCR mix (ROX). Volume reaksi untuk amplifikasi cDNA sebanyak 20,0 $\mu \mathrm{L}$ dengan final konsentrasi 1 xhot M aster mix (Rox), pasangan primer F/R 10 pmol (Tabel 2) masing-masing $250 \mathrm{nM}$, NFW (Nuclease Free Water) 
Tabel 1. Komposisi proksimat pakan moist yang digunakan untuk pemeliharaan benih lobster P. homarus

Table 1. Proximate composition of moist diet used for rearing juvenile of lobster P. homarus

\begin{tabular}{lccc}
\hline \multirow{2}{*}{$\begin{array}{l}\text { Komposisi proksimat } \\
\text { Proximate composition }\end{array}$} & \multicolumn{3}{c}{ Perlakuan (Treatments ) } \\
\cline { 2 - 4 } & A & B & C \\
\hline Air (Moisture) & 9.57 & 9.18 & 10.34 \\
Protein & 50.35 & 49.41 & 48.87 \\
Lemak (Fat) & 6.31 & 6.12 & 6.03 \\
Abu (Ash) & 12.18 & 12.41 & 12.18 \\
\hline
\end{tabular}

ditambahkan hingga volume $20 \mu \mathrm{L}$ dan cDNA $(0,01$ $\mathrm{ng} / \mathrm{uL}$ ). Kondisi suhu cycling untuk RT-qPCR terdiri atas suhu awal denaturasi $95^{\circ} \mathrm{C}$ ( 15 menit) diikuti dengan $95^{\circ} \mathrm{C}$ (15 detik) dan suhu annealing $60^{\circ} \mathrm{C}$ (30 detik) sebanyak 40 siklus dan suhu ekstensi akhir $60^{\circ} \mathrm{C}$ selama satu menit.

Penghitungan $\Delta \mathrm{Ct}$ dari threshold siklus PCR (Ct) gen yang diuji dinormalisasi secara relatif terhadap Ct 18sRNA (internal kontrol) pada sampel yang sama. Nilai $\Delta \Delta$ Ct dihitung dari $\Delta \mathrm{Ct}$ (kelompok sampel yang diuji) - $\Delta$ Ct (ekspresi awal). Representasi kelipatan relatif yang berbeda terhadap ekspresi awal dapat dihitung dengan $2-\Delta \Delta c t$

\section{HASIL DAN BAHASAN}

\section{Performa Pertumbuhan dan Sintasan Benih Lobster P. homarus}

Hasil yang diperoleh menunjukkan bahwa pemeliharaan benih lobster, P. homarus secara individu

Tabel 2. Sekuens primer yang digunakan untuk analisis gen terkait dengan imunitas benih lobster P. homarus dengan RT-qPCR

Table 2. Primer sequence that were used for immune - related gen analysis of juvenile $\mathbf{P}$. homarus by RT-qPCR

\begin{tabular}{|c|c|c|c|c|c|}
\hline $\begin{array}{l}\text { Sistem imun } \\
\text { Immune system }\end{array}$ & $\begin{array}{l}\text { Target gen } \\
\text { Gene target }\end{array}$ & $\begin{array}{l}\text { Nama } \\
\text { Name }\end{array}$ & Primer & Sequence (5"-3") & $\begin{array}{l}\text { Bank gen } \\
\text { Gene bank }\end{array}$ \\
\hline $\begin{array}{l}\text { proPO } \\
\text { activating system }\end{array}$ & Prophenoloxidase & proPO & proPO-F/R & $\begin{array}{l}\text { F:GAGATCGCAAGGGAGAACTG } \\
\text { R:CGTCAGTGAAGTCGAGACCA }\end{array}$ & EF 565469 \\
\hline Clotting System & Transglutaminase & Tgase & Tgase-F/R & $\begin{array}{l}\text { F:CCTCAGGATCTCCTTCACCA } \\
\text { R:TTGGGAAAACCTTCATTTCG }\end{array}$ & EE 572305 \\
\hline $\begin{array}{l}\text { Antimicrobial } \\
\text { peptide system }\end{array}$ & Clotting protein & $\mathrm{CP}$ & $\mathrm{CP}-\mathrm{F} / \mathrm{R}$ & $\begin{array}{l}\text { F:TCTTTGCGCAGTTGGTGATC } \\
\text { R:TGAGGTGACCGAGTGCAAAA }\end{array}$ & DQ984182 \\
\hline $\begin{array}{l}\text { Antioxidant defense } \\
\text { mechanism }\end{array}$ & $\begin{array}{l}\text { Glutathione } \\
\text { peroxidase }\end{array}$ & Gpo & GPO-F/R & $\begin{array}{l}\text { F:TTTTTCCGTGCAAAAAGGAC } \\
\text { R:TAATACGCGATGCCCCTAAC }\end{array}$ & AY 973252 \\
\hline \multirow[t]{2}{*}{$\begin{array}{l}\text { Anti-Lipopoly- } \\
\text { sacharide }\end{array}$} & & ALFHa-1 & ALFHa-1F/R & $\begin{array}{l}\text { F:CAGTCGTTCTGGTGTTGTTGGGAA } \\
\text { R:TTGTTGGGCATCCCTCTCGGTTAT }\end{array}$ & EU625516 \\
\hline & & ALFHa-2 & ALFHa-2F/R & $\begin{array}{l}\text { F:AGACTACCACTGACTTCGTGAGGA } \\
\text { R:TCTCGGGATGATCCGTTAACACCT }\end{array}$ & FC556430 \\
\hline $\begin{array}{l}\text { Serum amyloid } \\
\text { protein }\end{array}$ & SAA & SAA & SAA F/R & $\begin{array}{l}\text { F:TACCACTACCAGCACTCATCACCT } \\
\text { R:TCAAACACAGAGAATAGGCACGGG }\end{array}$ & EH116055 \\
\hline Internal control & 18s RNA & $18 \mathrm{~s}$ & $18 s-F / R$ & $\begin{array}{l}\text { F:AGCAGGCTGGTTTTTGCTTA } \\
\text { R:AGCAGGCTGGTTTTTGCTTA }\end{array}$ & AF 186250 \\
\hline
\end{tabular}


memberikan laju pertumbuhan bobot dan panjang yang tidak berbeda $(P>0,05)$ seperti terlihat pada Gambar 1. Hasil pengamatan bobot akhir benih lobster yang diberi pakan moist dengan penambahan ragi $(A)$, kombinasi probiotik (B), dan tanpa probiotik (C) masing-masing sebesar 3,77 $\pm 1,72 \mathrm{~g} ; 3,29 \pm 2,06 \mathrm{~g}$; dan $3,47 \pm 1,4 \mathrm{~g}$. Sementara, pertambahan bobot benih lobster selama tiga bulan pemeliharaan adalah (A) 3,4 g; (B) 2,92 g; dan (C) 3,1 g.

Bila dilihat dari komposisi proksimat pakan moist pelet, penambahan ragi $\mathrm{S}$. cerevisiae mempunyai kandungan protein $50,35 \%$ dibandingkan pakan moist yang ditambahkan kombinasi probiotik $(49,41 \%)$ dan tanpa probiotik $(48,87 \%$. Perbedaan kandungan protein yang relatif kecil $(0,5 \% 1,5 \%$, kemungkinan menyebabkan tidak adanya perbedaan pertumbuhan bobot dan panjang pada benih lobster. Selain itu, diduga efek mode of action probiotik yang diberikan tidak terekspresi terhadap performa pertumbuhan dan sintasan, namun terlihat pada imunitas. Oelschlaeger (2010) menyatakan bahwa di antara mode of action probiotik dapat untuk memodulasi pertahanan usus host (lobster) meliputi innate maupun acquired sistem imun dan aksi ini sangat penting untuk mencegah dan terapi infeksi penyakit dan treatmen inflamasi sistem pencernakan. Hasil penelitian Jayakumar et al. (2011) menyatakan bahwa formulasi pakan pelet dengan perbedaan tingkat variasi protein yang relatif tinggi (54,9\% 45,92\% dan 35,88\%) menghasilkan performa petumbuhan yang berbeda pada juvenil lobster P. homarus. Sementara, hasil penelitian Daniel et al.

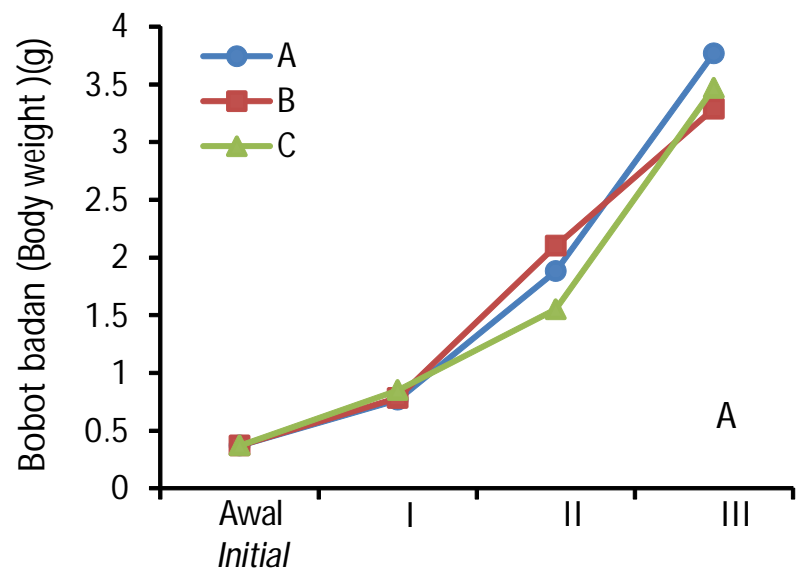

Waktu pemeliharaan (bulan) Culture period (months)
(2013) dan Daniel et al. (2010) menjelaskan tentang studi mengombinasikan probiotik dan prebiotik (synbiotic), dan terlihat adanya perubahan spesifik komposisi aktivitas mikroflora dalam gastrointestinal yang memberikan keuntungan pada host (lobster) dan kesehatan. Aksi sinergitik tersebut ditunjukkan dari kombinasi Bacillus spp. dan Mannan oligosaccharida yang merupakan prebiotik dalam pemeliharaan larva lobster Hommarus gammarus L. dan dapat meningkatkan performa pertumbuhan dan sintasan.

Besarnya sintasan benih lobster yang dipelihara secara individu pada pemberian pakan moist dengan penambahan ragi $(A)$, kombinasi probiotik $(B)$, dan tanpa probiotik (C), masing-masing sebesar $32,22 \%$ 29,63\% dan 33,33\% Hal ini tidak menunjukkan perbedaan nyata $(P>0,05)$. Mortalitas terjadi karena kegagalan pada saat benih lobster mengalami pergantian kulit. Sifat karnivor pada benih lobster sangat dominan sesuai dengan kondisi di alam. Kebiasaan memangsa hewan hidup (ikan atau krustasea kecil) menjadikan benih lobster relatif sulit untuk dialihkan ke makanan buatan (artificial diet).

\section{Total Hemosit}

Hasil pengamatan total hemosit pada benih lobsters terlihat bahwa pemberian moist pelet dengan penambahan probiotik maupun tanpa probiotik, memberikan jumlah hemosit yang berbeda. Pada perlakuan A (pakan moist yang ditambah ragi $\mathrm{S}$. cerevisiae) tertinggi dalam menghasilkan hemosit (196,5 x 104 sel/mL) (Gambar 3), sedangkan jumlah

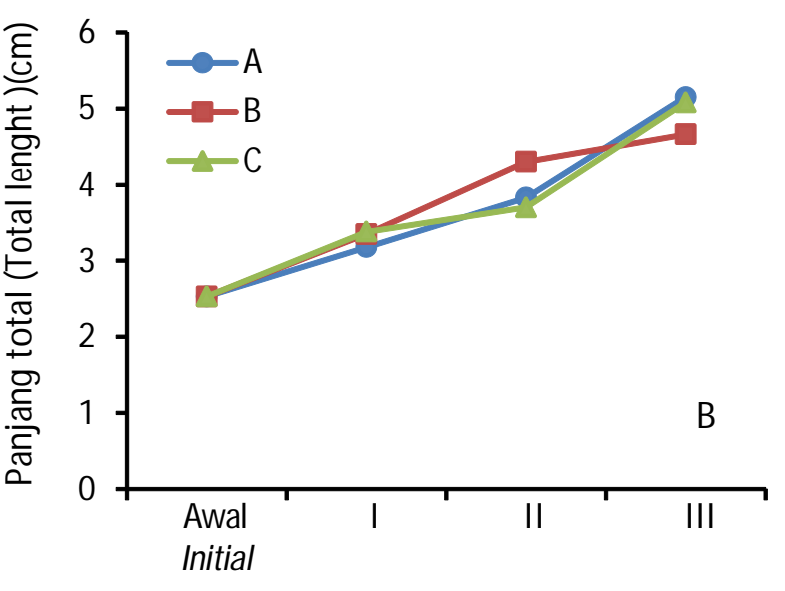

Waktu pemeliharaan (bulan) Culture period (months)

Gambar 1. Keragaan (A) pertumbuhan bobot $(\mathrm{g})$ dan $(\mathrm{B})$ panjang total $(\mathrm{cm})$ benih lobster P. homarus yang dipelihara secara individu dengan pakan moist yang ditambah (A) ragi S. cerevisiae, (B) kombinasi probiotik, dan (C) tanpa probiotik

Figure 1. Growth performance of body weight $(\mathrm{g})$ and total length $(\mathrm{cm})$ juvenile of spiny lobster $\mathbf{P}$. homarus reared with individually system and fed moist diets supplemented with (A) yeast $\mathbf{S}$. cerevisiae (B) combination of probiotic, and (C) without probiotic 


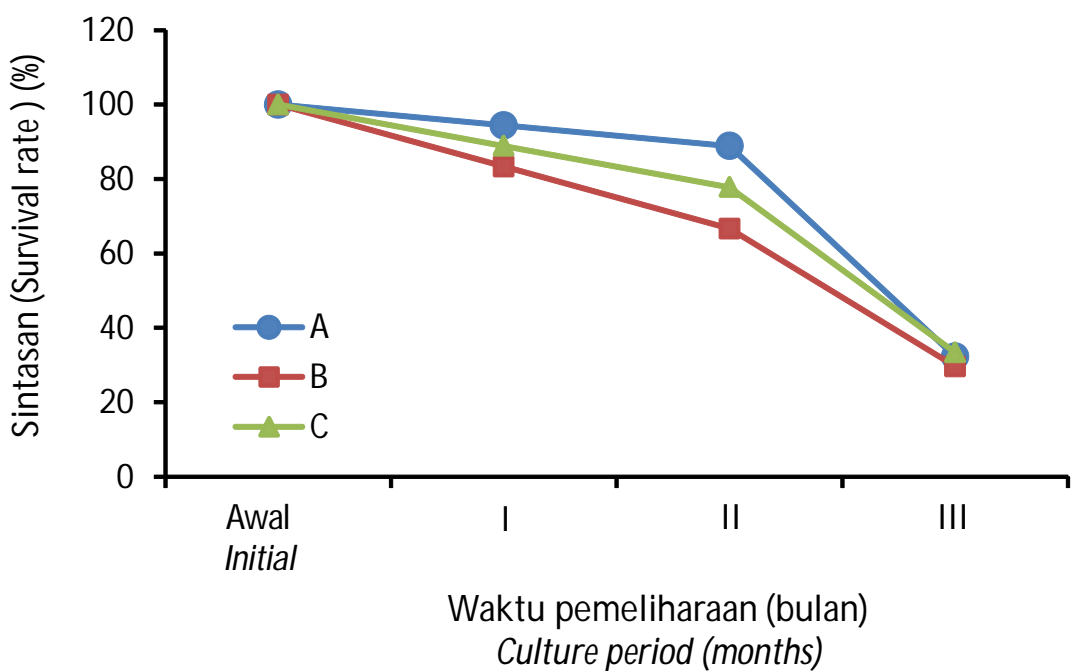

Gambar 2. Sintasan (\% benih lobster P. homarus yang dipelihara secara individu dengan pakan moist yang ditambahkan (A) ragi S. cerevisiae, (B) kombinasi probiotik, dan (C) tanpa probiotik

Figure 2. Survival rate (\%) of juvenile spiny lobster, P. homarus reared with individual system and fed with moist diets supplemented with (A) yeast S. cerevisiae (B) combination of probiotic, and (C) without probiotic

hemosit terendah pada perlakuan C (tanpa probiotik). Peran ragi $\mathrm{S}$. cerevisiae dengan dinding sel yang mengandung $\beta(1,3$ dan 1,6$)$ glukan dapat sebagai imunomodulator untuk meningkatkan jumlah dan kemampuan sel T, sel B (pada ikan), sel hemosit (pada krustasea) dan makrofag dalam rangka melawan infeksi penyakit. Hemosit berperan penting dalam meregulasi respons imun pada krustasea, walaupun pengukurannya akan lebih kompleks dengan perbedaan jenis kelamin dan ukuran lobster yang diamati (Huu \& Jones, 2014). Pada krustasea, hemosit terlibat dalam reaksi pertahanan tubuh (immediate defense reaction), seperti modulasi, enkapsulasi, dan fagositosis. Selain itu, hemosit membantu pada perbaikan jaringan yang rusak pada tubuh melalui proses regenerasi dan penyembuhan.

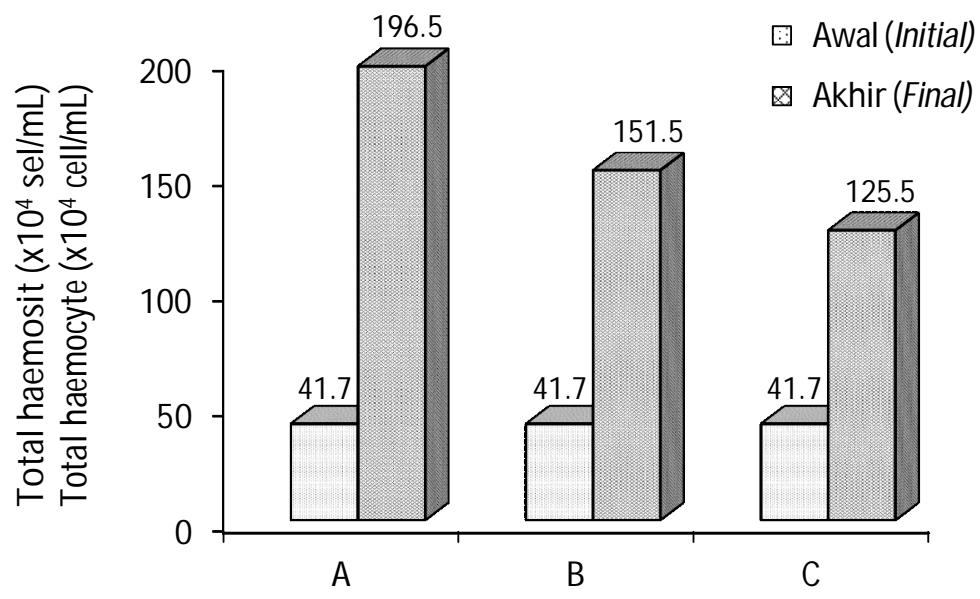

Gambar 3. Total hemosit (x $10^{4} \mathrm{sel} / \mathrm{mL}$ ) benih P. homarus dengan pemberian pakan moist pelet yang ditambahkan (A) ragi S. cerevisiae, (B) kombinasi probiotik, dan $(C)$ tanpa probiotik

Figure 3. Total hemocytes $\left(\times 10^{4} \mathrm{cell} / \mathrm{mL}\right)$ of juvenile lobster $\mathbf{P}$. homarus reared with fed of moist diet supplemented with (A) yeast S. cerevisiae, (B) probiotic, and (C) without probiotic 


\section{Status Imun Benih Lobster P. homarus}

Hasil analisis ekspresi gen yang terkait imunitas dengan target gen ALF-1, ALF-2, SAA, ProPO, Tgase, $C P$, dan GPO pada benih lobster sebelum diuji tantang dengan V. harveyi tertera pada Gambar 4. Analisis ekspresi gen dilakukan pada akhir penelitian.

Pada Gambar 4 menunjukkan bahwa hasil analisis ekspresi gen yang terkait imunitas pada benih lobster setelah tiga bulan pemeliharaan (sebelum uji tantang) pada perlakuan A (ragi S. cerevisiae) dan B kombinasi probiotik (Alteromonas sp. BY-9 dan Bacillus cereus $B C$ ), terlihat lebih tinggi status imunnya pada target gen ALFHa-1, ALFHa-2, SAA, ProPO, dan $\mathrm{CP}$ dibandingkan dengan perlakuan tanpa penambahan probiotik. Tingkat ekspresi mRNA sebagai indikator imunitas pada benih lobster sebelum uji tantang dengan $\mathrm{V}$. harveyi masih relatif rendah. Pada benih lobster dengan pakan moist yang ditambahkan ragi (A), terlihat kelipatan imunitas dari target gen ALF Ha-1 dan ALFHa-2 adalah sama (0,07 kali), sedangkan pada target gen SAA, ProPO, dan CP ada peningkatan ekspresi masing-masing 0,$17 ; 0,19$; dan 0,11 kali. Sementara, pada target gen Tgase dan GPO menunjukkan ekspresi yang rendah (0,04 dan 0,01 kali). Pada benih dengan perlakuan pakan moist pelet yang ditambah kombinasi probiotik (B) menunjukkan ekspresi imunitas yang lebih tinggi pada ALFHa- $1(0,17$ kali), SAA (0,26 kali), dan CP (0,19 kali), sedangkan pada empat target gen lainnya menunjukkan ekspresi imunitas yang rendah yaitu ALFHa-2 ( 0,06 kali), Pro PO $(0,08$ kali), Tgase $(0,02$ kali), dan GPO $(0,03$ kali). Sementara, pada benih lobster yang diberi pakan moist tanpa probiotik (C), kelipatan imunitas pada tujuh target gen hanya berkisar antara 0,02-0,13 kali.

S. cereviceae adalah ragi yang tergolong eukaryote, mempunyai dinding sel dengan kandungan $\beta$ ( 1,3 dan $1,6)$ glukan, kitin, dan manoprotein. $\beta(1,3$ dan 1,6$)$ glukan merupakan substansi esensial dan memiliki kemampuan menstimulasi secara nonspesifik terhadap respons imun (imunostimulan). Komposisi kimia ragi S. cereviceae terdiri atas protein kasar (50\%52\%), karbohidrat $(30 \% 37 \%$, lemak $(4 \% 5 \%$, dan mineral $(7 \%$ $8 \%$ (Ahmad, 2005). S. cereviceae juga mempunyai beberapa enzim dan berfungsi penting di antaranya peptidase, zimase, dan intervase. Enzim peptidase mempunyai 92 gen dan enzim tersebut yang homolog inaktif sebanyak 32 gen. Adanya $\beta(1,3$ dan 1,6$)$ glukan dapat meningkatkan fungsi imun termasuk fagositosis dan stimulasi RES (Reticula Endothelial System) dan enzim dengan gen homolog aktif dapat mengekspresikan peningkatan imunitas (Ahmad, 2005).

Peran Alteromonas sp. BY-9 adalah menekan adanya infeksi Vibrio (biological control) dalam pemeliharaan udang dan kepiting, sehingga media pemeliharaan menjadi sehat. Sementara, Bacillus cereus BC merupakan probiotik yang berperan dalam sistem pencernaan,

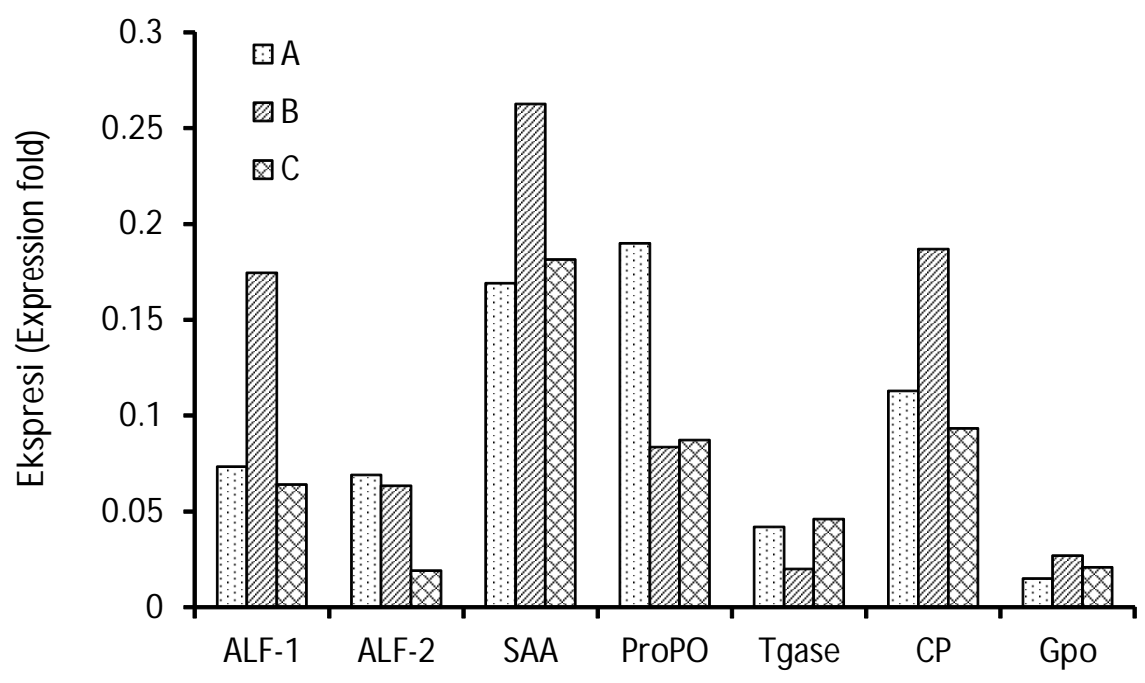

Gambar 4. Tingkat ekspresi mRNA dari ALFHa-1, ALFHa-2, SAA, ProPO, Tgase, CP, dan GPO pada hemosit benih lobster $P$. homarus setelah tiga bulan pemeliharaan (sebelum uji tantang dengan $\mathrm{V}$. harveyi). Benih lobster diberi pakan moist pelet dengan penambahan (A) ragi S. cerevisiae, (B) kombinasi probiotik, dan (C) tanpa probiotik

Figure 4. Expression value mRNA of ALF-1, ALF-2, SAA, ProPO, Tgase, CP, and GPO on hemocytes of juvenile $\mathbf{P}$. homarus after three months reared (before challenge test with $\mathbf{V}$. harveyi). Juvenile lobster fed moist diets supplemented with (A) yeast S. cerevisiae, (B) probiotic, and (C) without probiotic 
sehingga fungsi usus lobster menjadi baik, dimungkinkan tingkat kecernaan lebih efisien. Kombinasi peran inilah yang menyebabkan benih lobster yang selama pemeliharaannya menggunakan kombinasi dua jenis probiotik tersebut menunjukkan ekspresi imun yang lebih baik setelah melalui analisis ekspresi gen yang terkait imunitas, walaupun belum diuji tantang dengan $\mathrm{V}$. harveyi penyebab red body disease.

Sel hemosit dalam hemolim, berimplikasi pada perbedaan respons kekebalan, di antaranya melanisasi dan coagulasi yang dimediasi oleh pelepasan efektor hemosit, seperti prophenoloxidase (propo) activating sistem, transglutaminase atau anti microbial peptida. Dalam sistem immunerelated protein pada krustasea, dapat digambarkan sebagai clotting protein, lysozyme, Lipopolysacharide aglutinin, dan $\beta$ glucan-binding protein.

Mekanisme kekebalan tubuh pada krustasea termasuk lobster tidak seperti pada ikan yang mempunyai sistem imunoglobulin. Imunoglobulin pada krustasea dikenal dengan Prophenoloxidase Activating enzim (PPA). PPA merupakan protein yang berlokasi di sel granular hemosit dan dapat diaktifkan oleh lipopolysacharida (LPS) dan $\beta$ 1,3-Glucan; yang dapat merangsang prophenoloxidase menjadi phenoloxidase. Sebagai akibat dari perubahan ini akan dihasilkan semacam Proteine Opsonin Factor yang dapat menginduksi sel-sel agranuler hemosit untuk melakukan proses fagositosis. Sel hemosit juga melakukan degranulasi dan beberapa protein akan dilepas sebagai respons imun (Van de Braak, 2002).

\section{Ekspresi Gen yang Terkait Imunitas}

\section{Anti-Lipopolysacharida Faktor}

Pengujian ekspresi gen imunitas dengan menggunakan RT-qPCR pada benih lobster dimaksudkan untuk mengetahui pengaturan transkripsi gen selama uji tantang dengan menginfeksikan V. harveyi. Tingkat ekspresi gen mRNA secara individual dari benih lobster dinormalisasi menggunakan 18srRNA sebagai reference endogenous (kontrol internal), kemudian diekspresikan terhadap ekspresi dasar pada paparan nol (0) jam. Hasil yang diperoleh disajikan dalam masing-masing pengaturan mekanisme pertahanan pada lobster.

Sistem aktivasi gen ALFHa-1 dan ALFHa-2 (antilipopolysacharida factor) terlihat signifikan terhadap peningkatan regulasi imun pada perlakuan A (pakan moist dengan ragi, S. cerevisiae) dari 24 jam hingga 96 jam setelah uji tantang. Tingkat transkripsional ALFHa1 mencapai 2,09 kali (24 jam), dan 4,79 kali (96 jam). Sementara, pada perlakuan B (pakan moist dengan kombinasi probiotik) terlihat ekspresi imunitas 1,183,32 kali (24-48 jam) dan 2,20 kali (96 jam), sedangkan perlakuan C (tanpa probiotik) terlihat kelipatan ekspresi sebesar 2,3-2,9 kali (24-96 jam) setelah uji tantang V. harveyi (Gambar 5A). Pada ALFHa-2 ekspresi imunitas benih lobster pada perlakuan (B) dan (C) terlihat lebih tinggi pada 24 jam setelah uji tantang (Gambar 5B). Pemberian pakan moist dengan kombinasi probiotik (B) dan tanpa probiotik (C) masing-masing menunjukkan tingkat ekspresi 3,69 dan 3,09 kali pada 24 jam setelah uji tantang. Anti Lipopolysacharide Factor (ALF) merupakan bagian kecil dari protein dasar dan berperan untuk menetralisir lipopolysaccharida (LPS). Peran lain dari ALF adalah terlibat dalam penghambatan infeksi fungi dan bahkan replikasi atau pertumbuhan virus (Wang et al., 2010). Dari hasil ekspresi imun ALFHa-2 pada benih lobster dengan perlakuan $\mathrm{A}$ (pakan moist dengan ragi, $\mathrm{S}$. cerevisiae) menunjukkan nilai kuantitatif yang rendah. Hal ini diduga karena pakan moist dengan penambahan ragi diberikan melalui oral, sehingga peningkatan atau penurunan mekanisme pertahanan tubuh tergantung pada jumlah ragi (dengan kandungan $\beta$ glukan) yang dikonsumsi. Oleh karena itu, respons terhadap hewan uji sangat bervariasi tergantung pada ada atau tidaknya reseptor yang dikenal oleh komponen glukosa dari $\beta$ $(1,3$ dan 1,6$)$ glukan.

\section{Pro PO Activating System}

Sistem aktivasi gen proPO (prophenoloxidase) terlihat signifikan terhadap peningkatan regulasi imun pada perlakuan A (pakan moist dengan ragi, S. cerevisiae) dan $B$ (pakan moist dengan kombinasi probiotik) dari 24, 48, dan 96 jam setelah uji tantang. Tingkat transkripsional proPO pada perlakuan A (pakan moist dengan ragi, S. cerevisiae) mencapai 6,00 kali (24 jam); 8,59 kali (48 jam) dan 3,42 kali (96 jam), sedangkan pada perlakuan $B$ (pakan moist dengan kombinasi probiotik) diperoleh 24,53 kali (48 jam) dan 7,33 kali (96 jam). Sementara, pada perlakuan C (tanpa probiotik) terlihat pada 24 dan 72 jam setelah uji tantang V. harveyi mencapai tingkat transkripsi 2,09 dan 4,7 kali (Gambar 6).

Sistem aktivasi proPO pada krustasea merupakan aspek penting dari innate immunity, dan tahapan awal dalam mengkatal isa melanisasi pada invertebrata. Wang et al. (2010) menyatakan bahwa tingkat ekpresi proPO meningkat pada Fenneropenaeus chinensis yang terinfeksi Vibrio anguillarum. Peningkatan regulasi proPO merupakan hal yang penting sebagai respons melawan infeksi Vibrio. Proses aktivasi sistem ProPO memerlukan partisipasi protease dan mekanisme ini memerlukan ketepatan pengontrolan untuk mencegah kerusakan jaringan. Phenoloxydase diproduksi dari pengaktifan prophenoloxidase (proPO system) sebagai 

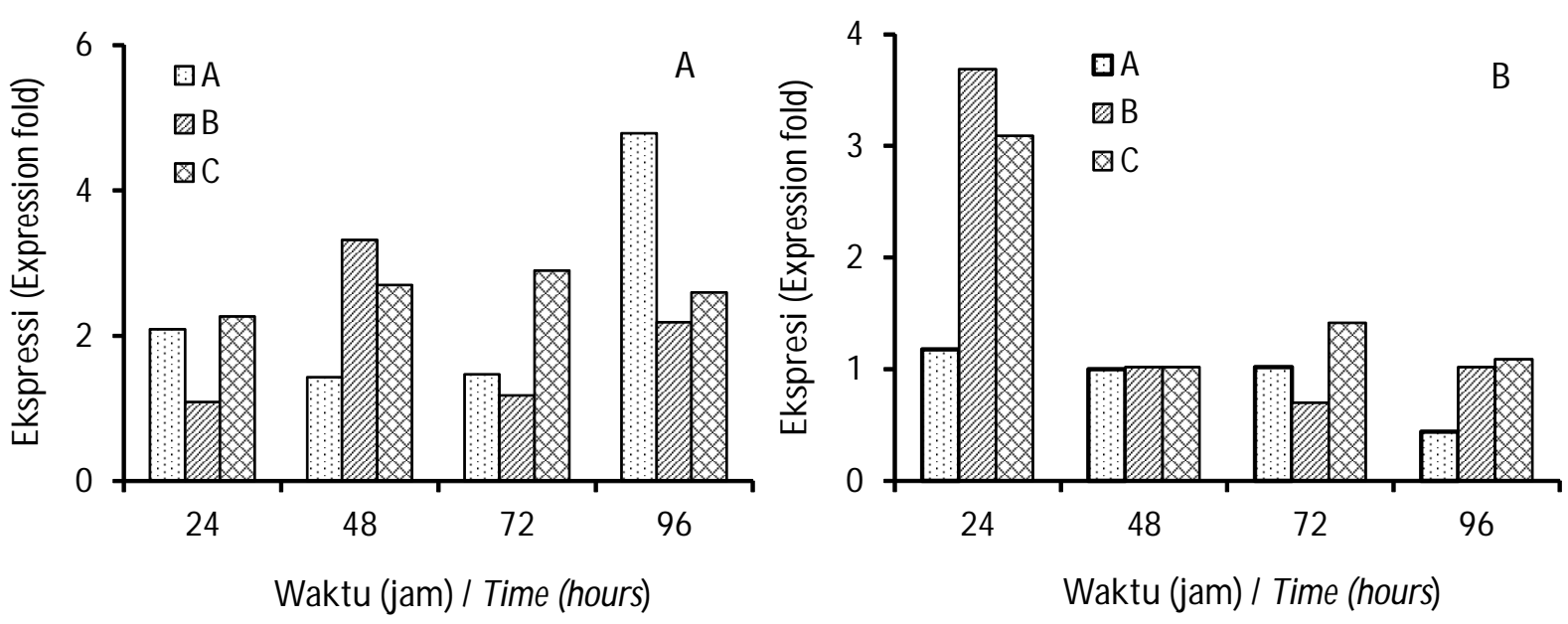

Gambar 5. Tingkat ekspresi mRNA dari anti-lipopolysacharide factor (ALFHa-1 (A) dan ALFHa-2 (B)) dalam hemosit lobster P. homarus setelah diuji tantang dengan V. harveyi. Benih lobster diberi pakan moist pelet dengan penambahan (A) ragi S. cerevisiae, (B) kombinasi probiotik, (C) tanpa probiotik

Figure 5. Expression value mRNA of anti-lipopolysacharide factor (ALFHa-1 (A) and ALFHa-2 (B)) in juvenile lobster $\mathbf{P}$. homarus hemocytes after $\mathbf{V}$. harveyi challenge test. Juvenile lobster fed moist diets supplemented with (A) yeast S. cerevisiae, (B) combination of probiotic, and (C) without probiotic

fenomena "cascade" dengan beberapa cara untuk performansi fungsi organ.

Sistem imun pada benih lobster sebagaimana pada spesies invertebrata lain, tergantung pada innate immunity. Innate immunity terbagi dalam pertahanan humoral (mengaktifasi beberapa bagian proteolytic seperti sistem prophenoloxidase/proPO, mekanisme clotting hemolim, melanisasi respons imun antimikroba) dan pertahanan seluler (fagositosis, enkapsulasi, degranulasi seluler, dan pelepasan faktor-faktor pertahanan). Innate immunity pada invertebrata dimediasi oleh sel hemosit yang bersirkulasi.

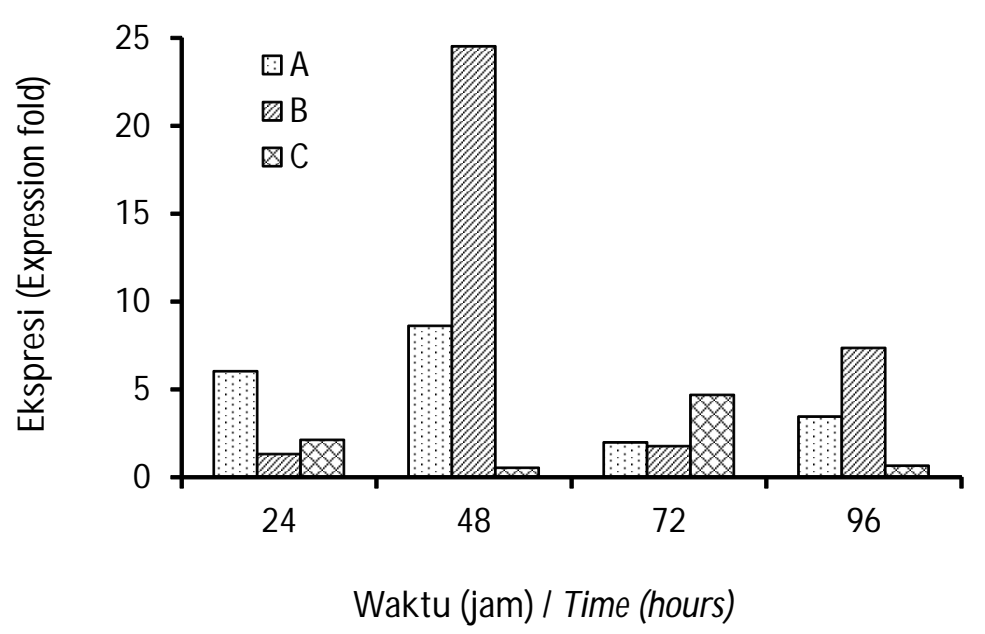

Gambar 6. Tingkat ekspresi mRNA dari proPO activating system (prophenoloxidaseProPO) dalam hemosit benih lobster P. homarus setelah diuji tantang dengan $V$. harveyi. Benih lobster diberi pakan moist pelet dengan penambahan (A) ragi S. cerevisiae, (B) kombnasi probiotik, dan (C) tanpa probiotik

Figure 6. Expression value mRNA of proPO activating system (prophenoloxidase-ProPO) in juvenile lobster $\mathbf{P}$. homarus hemocytes after $\mathbf{V}$. harveyi challenge test. Juvenile lobster fed moist diets supplemented with (A) yeast $\mathbf{S}$. cerevisiae, (B) probiotic, and (C) without probiotic 


\section{Hemolymp Clotting Mechanism}

Transglutaminase (Tgase) dan clotting protein (CP) berperan dalam clotting sistem krustasea. Tingkat ekspresi gen Tgase benih lobster dengan pakan moist yang ditambahkan ragi, S. cerevisiae relatif lebih tinggi 1,25-1,71 kali daripada perlakuan C (pakan moist tanpa probiotik) setelah 24-96 jam terpapar hanya 0,84-1,45 kali. Pada pakan moist dengan kombinasi probiotik setelah terpapar selama 24, 48, 72 jam hingga 96 jam dengan V. harveyi menunjukkan kelipatan ekspresi gen Tgase yang tinggi masing-masing sebesar 1,28; 2,37; 6,36; dan 16,24 kali (Gambar 7A).

Ekspresi gen $\mathrm{CP}$ menunjukkan pengaturan imun yang meningkat sejak 24, 48, 72, dan 96 jam setelah uji tantang dengan V. harveyi pada pemberian pakan moist yang ditambahkan ragi S. cerevisiae (Gambar 7B). Kelipatan ekspresi imunitas yang mengkode gen CP sebesar 11,06 kali (24 jam), 14,52 kali (48 jam), 2,30 kali (72 jam), dan 8,2 k,li (96 jam). Pada benih lobster yang diberi pakan moist dengan kombinasi probiotik dan tanpa probiotik, kelipatan ekspresi gen CP tidak berbeda nyata.

Pada lobster yang mengalami luka, sistem clotting protein berperan cepat untuk mencegah hilangnya hemolim. Sistem clotting juga terlibat dalam memobilisasi pencegahan tersebarnya patogen melalui hemocoel. Sementara, pada transglutaminase (Tgase) berperan dalam memediasi koagulasi hemolim dengan men-triger polimerisasi clotting protein. Penggunaan RNA interferens menunjukkan bahwa Tgase dan CP berperan dalam pertahanan dan mencegah bakteri
(V. penaecida) dan virus (WSSV) pada udang P. japonicus (Maningas et al., 2008).

\section{Antioxidant Defense Mechanism}

Glutathione peroxidase (GPO) adalah enzim antioksidan yang memediasi kerusakan oksidatif. Tingkat ekspresi imun dengan targen gen GPO pada perlakuan $\mathrm{A}$ (pakan moist dengan penambahan ragi, $\mathrm{S}$. cerevisiae) menunjukkan tingkat yang rendah yaitu 3,62 kali (24 jam); 1,15 kali (48 jam); 2,51 kali (72 jam); dan 2,05 kali (96 jam). Sementara, pada perlakuan kombinasi probiotik tingkat ekspresi diperoleh pada 48-96 jam setelah uji tantang dengan $\mathrm{V}$. harveyi yaitu 9,22 kali (48 jam); 13,00 kali (72 jam); dan 37,75 kali (96 jam) (Gambar 8). Pada perlakuan C (tanpa probiotik) ekspresi imun yang tinggi terlihat setelah benih lobster terpapar V. harveyi 24 jam $(8,61$ kali), 72 jam (19,9 kali), dan 96 jam (15,61 kali). Gen GPO mentransformasi hidrogenperoksida menjadi air dan oksigen dengan katalisasi sebelum radikal hidroksil dapat dihasilkan. Bila lobster terinfeksi penyakit, maka akan terjadi stres oksidatif.

Pengujian ekspresi gen yang berhubungan dengan imunitas menggunakan target gen yang mengkode serum amyloid protein (SAA) menunjukkan ekspresi yang bervariasi (Gambar 9). Pada paparan 24 jam, benih lobster yang dipelihara dengan pakan moist pelet dan penambahan ragi $S$. cerevisiae memberikan kelipatan ekspresi yang tinggi (5,07 kali), namun pada 48, 72, dan 96 jam, ekspresi imunitas menurun masingmasing sebesar 2,90; 2,36; dan 3,91 kali. Ekspresi imunitas pada benih lobster yang diberi pakan moist
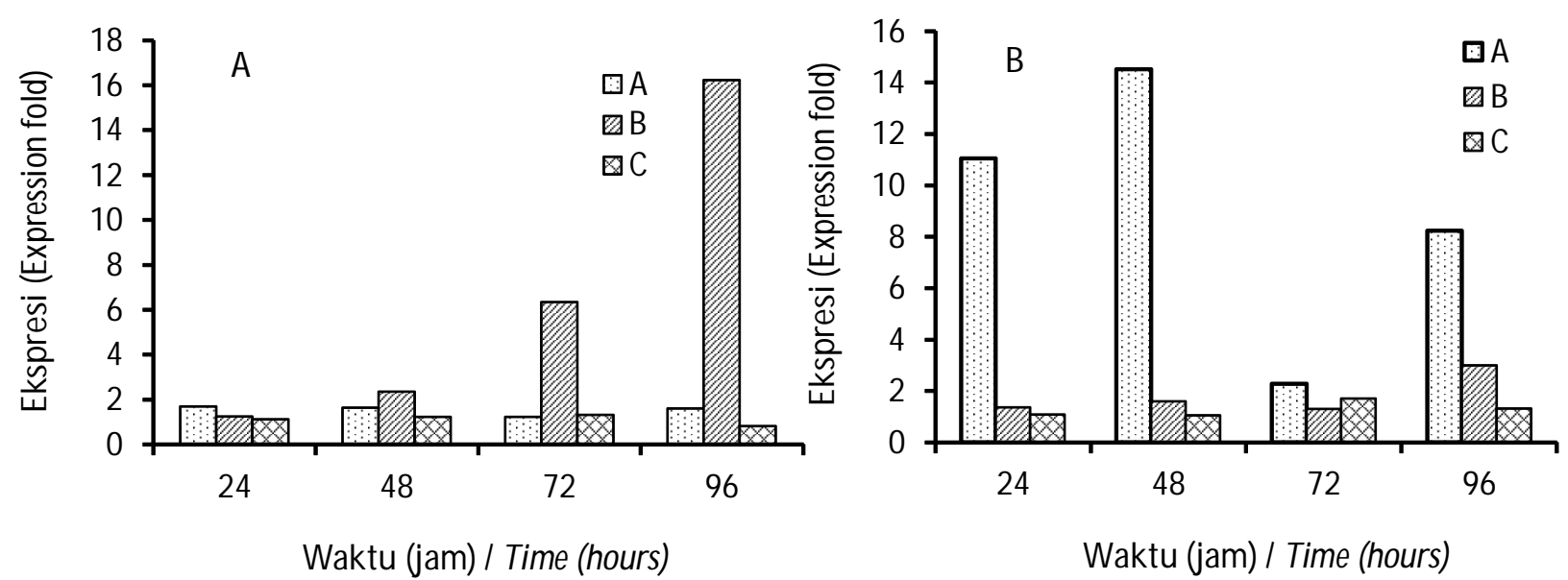

Gambar 7. Tingkat ekspresi mRNA dari transglutaminase (Tgase) (A) dan clotting protein (CP) (B) dalam hemosit benih lobster, P. homarus setelah diuji tantang dengan V. harveyi. Benih lobster diberi pakan moist pelet dengan penambahan (A) ragi S. cerevisiae, (B) kombinasi probiotik, dan (C) tanpa probiotik

Figure 7. Expression value mRNA of transglutaminase (Tgase) (A) and clotting protein (CP) (B) in juvenile lobster P. homarus hemocytes after $\mathbf{V}$. harveyi challenge test. Juvenile lobster fed moist diets supplemented with (A) yeast $\mathbf{S}$. cerevisiae, (B) combination of probiotic, and (C) without probiotic 


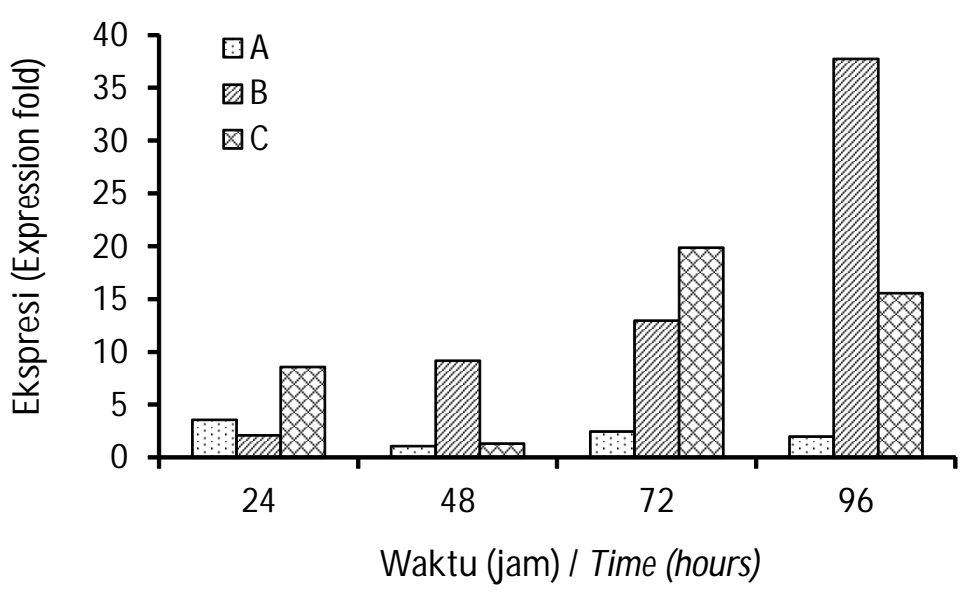

Gambar 8. Tingkat ekspresi mRNA dari glutathione peroxidase (GPO) pada hemosit benih lobster P. homarus setelah diuji tantang dengan V. harveyi. Benih lobster diberi pakan moist pelet dengan penambahan (A) ragi S. cerevisiae, (B) kombinasi probiotik, dan (C) tanpa probiotik

Figure 8. Expression value mRNA of glutathione peroxidase (GPO) in juvenile lobster, P. homarus hemocytes after $\mathbf{V}$. harveyi challenge test. Juvenile lobster fed moist diets supplemented with (A) yeast $\mathbf{S}$. cerevisiae, (B) combination of probiotic, and (C) without probiotic

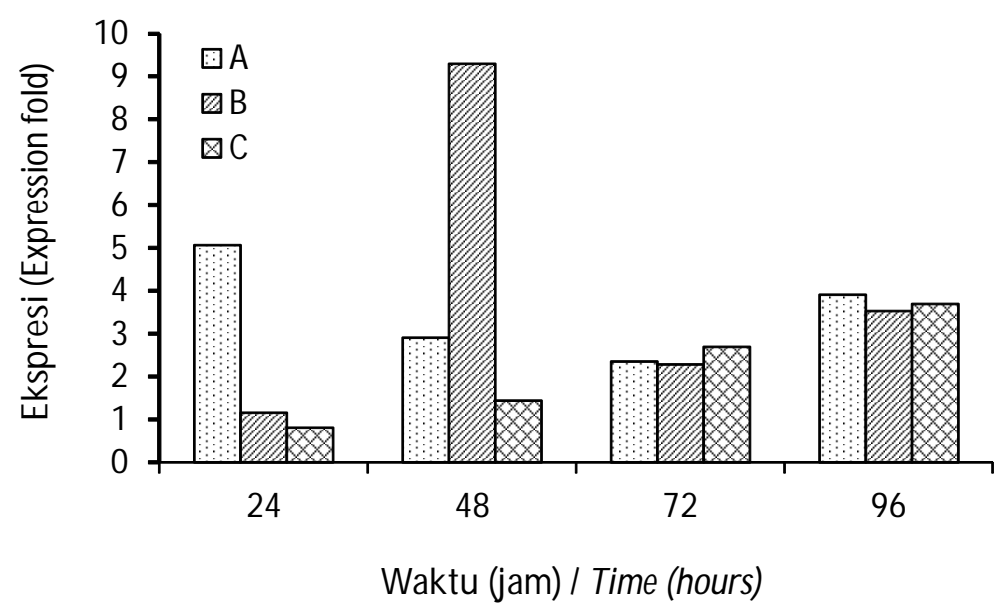

Gambar 9. Tingkat ekspresi mRNA dari serum amyloid protein (SAA) pada hemosit benih lobster P. homarus setelah diuji tantang dengan V. harveyi. Benih lobster diberi pakan moist pelet dengan penambahan (A) ragi $\mathrm{S}$. cerevisiae, (B) kombinasi probiotik, dan (C) tanpa probiotik

Figure 9. Expression value mRNA of serum amyloid protein (SAA) in juvenile lobster $\mathbf{P}$. homarus hemocytes after $\mathbf{V}$. harveyi challenge test. Juvenile lobster fed moist diets supplemented with (A) yeast $\mathbf{S}$. cerevisiae, (B) combination of probiotic, and (C) without probiotic

dengan kombinasi probiotik pada 48 jam terpapar V. harveyi menunjukkan nilai yang tinggi 9,29 kali. Imunitas lobster yang diberi moist tanpa probiotik menunjukkan peningkatan imunnya setelah 96 jam $(3,7$ kali).
Respons imun yang terkait dengan gen imunitas pada lobster terhadap infeksi penyakit bakterial akan membantu menjelaskan pengaturan imun inang (lobster) melawan infeksi penyakit tersebut. Penggunaan RT-q PCR untuk mengkarakterisasi 
perubahan ekspresi mRNA dari tujuh gen target yang terkait imunitas setelah diuji tantang dengan $\mathrm{V}$. harveyi (penyakit bakterial penyebab red body disease) dapat membuktikan implikasi fungsi yang jelas terhadap peran penggunaan probiotik yang berasal dari mikroba terhadap peningkatan respons imunitas. Dari hasil tersebut terbukti bahwa penggunaan ragi, S. cerevisiae, probiotik Alteromonas Sp. BY-9 dan B. cereus BC) merupakan satu di antara metode pencegahan penyakit infeksi (virus dan bakteri) melalui peningkatan imunitas dalam produksi lobster.

\section{KESIMPULAN}

Pertumbuhan bobot, panjang, dan sintasan benih lobster tidak bebeda nyata antar perlakuan. Tingkat ekspresi imunitas terhadap tujuh gen target (ALFHa-1, ALFHa-2, Pro PO, Gpo, CP, SAA, dan GPo) pada benih lobster $P$. homarus yang diberi pakan moist pelet dengan penambahan ragi $S$. cerevisiae dan kombinasi probiotik Alteromonas sp. BY-9 dan B. cereus $\mathrm{BC}$ mengalami peningkatan dibandingkan dengan tanpa probiotik setelah uji tantang dengan V. harveyi (penyebab red body disease).

\section{UCAPAN TERIMA KASIH}

Penelitian ini dilaksanakan dengan pendanaan dari DIPA 2015 Balai Besar Penelitian dan Pengembangan Budidaya Laut Gondol, Kementerian Kelautan dan Perikanan. Penulis juga mengucapkan terima kasih kepada semua teknisi litkayasa laboratorium bioteknologi dan laboratorium pakan-nutrisi atas bantuannya dalam pelaksanaan penelitian ini.

\section{DAFTAR ACUAN}

Ahmad, R.Z. (2005). Pemanfaatan khamir S. cereviceae untuk ternak. Wartazoa, 15(1), 49-55.

Anh, T.L., \& Jones,C. (2014). Status report of Vietnam lobster grow-out. Proceeding of the International Lobster Aquaculture Symposium. Lombok, Indonesia, 22-25 April 2014, p. 82-86.

Anonymous. (2007). Milky haemolymp disease of spiny lobsters (Panulirus spp.). OIE Aquatic Animal Disease Cards, p. 1-3.

Balcazar, J.L., Rojas-Luna, T., \& Cunningham, D.P. (2007). Effect of the addition of four potential probiotic strains on the survival of pacific white shrimp (Litopenaeus vannamei) following immersion challenge with Vibrio parahaemolyticus. Journal of Invertebrate Pathology, 96, 147-150.

Beale, K.M., Towle, D.W. Jayasundra, N., Smith, C.M., Sields, J.D., Small, H.J. \& Greenwood, S.J. (2009). Anti-polysaccharide factors in the American lobster Homarus americanus: Molecular characteriza- tion and transcriptional response to Vibrio fluvialis challenge. Comp. Biochem. Physiol Part D Genomic Proteomics, 3(4), 263-269.

Clark, K.F. (2013). Discovery of novel molecular immune mediators in the American lobster (Homarus americanus) during bacterial, eukaryotic parasitic and viral challenges. Doctor of Philoso phy a thesis. University of Prince Edward Island.

Clark, K.F., Greenwood, S.J., Acorn, A.R., \& Byrne, P.J. (2013). Molecular immune response of the American lobster (Homarus americanus) to the white spot syndrome virus. J. Invertebr. Pathol., 114(3), 298308.

Daniels, C.L., Marrifield, D.L., Boothroyd, D.P., Davies, S.J., Factor, J.R., \& Arnold, K.E. (2010). Effect of dietary Bacillus spp. and Mannan Oligosaccharides (MOS) on European lobster (Homarus gammarus L) Iarval growth performance, gut morphology and gut microbiote. Aquaculture, 304, 49-57.

Daniels, C.L., Marrifield, D.L., Ringo, E., \& Davies, S.J. (2013). Probiotic, Prebiotic, symbiotic application for the improvement of larval European lobsters (Homarus gammarus) culture. Aquacult., 416-417, 396-406.

Fu, L.L., Wang, Y., Wu, Z.C., \& Li, W.F. (2011). In vivo assesment for oral delivery of Bacillus subtilis harboring a viral protein (VP28) against white spot syndrome virus in Litopenaeus vannamei. Aquaculture, 322-323, 33-38.

Hauton, C., Brockton, V., \& Smith, V.J. (2013). Changes in immunity gen expression and resistance to bacterial infection in lobster (Homarus americanus) post-larva stage VI following acute or chronic exposure to immunity stimulating compounds. J. Invertebr. Pathol., 114(3), 289-297.

Huu, H.D., \& Jones, C.M. (2014). Effect of dietary mannan oligosaccharide supplementation on juvenile spiny lobster Panulirus homarus (Palinuridae). Aquaculture, 432, 258-264.

Jayakumar, V.L., Ramanathan, N., Jeyaseelan, M.J.P., \& Athithan, S. (2011). Growth Performance of spiny lobster Panulirus homarus (Linnaeus) administered with formulated pellet feeds. Indian J. Fish, 58(3), 95-101.

Jimenez-Vega, F., Yepiz-Plascencia, G., Soderhall, K., $\&$ Vargas-Albores, F. (2004). A single WAP domaincontaining protein from Litopenaeus vannamei hemocytes. Biomedical and Biophisical Research Communication, 314, 681-687.

Karla,Y. Leyva-Madrigal, Luna-Gonzalez, A., EscobedoBonilla,C.M., Yesus,A., Fierro-Coronado, \& Maldonado-Mendoza,I.E. (2011). Screening for potential probiotic bacteria to reduce prevalence 
of WSSV and IHHNV in white shrimp (Litopenaeus vannamei ) under experimental condition. Aquaculture, 322-323, 16-22.

Li, J., Tan, B., \& Mai, K. (2009). Dietary probiotic Bacillus $\mathrm{OJ}$ and isomaltooligosaccharides influence the intestine microbial populations, immune response and resistance to white spot syndrome virus in shrimp (Litopenaeus vannamei). Aquaculture, 291, 35-40.

Luis-Villasenor, I.E., Macias-Rodriguez, M.E., GomezGil, B., Ascencio-Valle, F., \& Campa-Cordova, A.I. (2011). Beneficial effect of four Bacillus strain on the larval cultivation of (Litopenaeus vannamei). Aquaculture, 321, 136-144.

Maningas ,M.B., Kondo, H., Hirono, I., Saito-Taki, T., \& Aoki, T. (2008). Essential function of transglutaminase and clotting protein in shrimp immunity. Mol. Immunol., 45, 1269-1275.

Nunan, L.M., Poulos, B.T., Navarro, S., Redman, R.M., \& Lightner, D.V. (2010). Milky hemolymph syndrome (MHS) in spiny lobsters, penaeid shrimp and crabs. Dis. Aquat. Organ., 91(2), 105-112.

Oelschlaeger, T.A. (2010). Mechanisms of probiotic actions - a review. International Journal of M edical Microbiology, 300, 57-62.

Priyambodo, B. (2014). Development of the lobster farming industry in Indonesia. Proceeding of the International Lobster Aquaculture Symposium. Lombok, Indonesia, 22-25 April 2014, p. 114-118.

Priyambodo, B., \& Sarifin (2009). Lobster Aquaculture Industry in Eastern Indonesia: Present status and prospects. Proceeding of an International Symposium. Nha Trang, Vietnam, 9-10 December 2008, p. 36-45.

Rodriquez, J., Espinosa, Y., Echeverria, F., Cardenas, G., Roman, R., \& Stern, S. (2007). Exposure to probiotics and â-1,3/1,6 - glucans in larviculture modifies the immune response of Penaeus vannamei juveniles and both the survival to White Spot Syndrome Virus challenge and pond culture. Aquaculture, 273, 405-415.

Shanks, S., Bahrawi, S., Priyambodo, B., \& Jones, C. (2014). Transport and husbandry of post-puerulus tropical spiny lobster. Proceeding of the International Lobster Aquaculture Symposium. Lombok, Indonesia, 22-25 April 2014, p. 55-60.

Sields, J.D. (2011). Diseases of spiny lobster: A review. Journal of Invertebrate Pathology, 106, 79-91.

Van de Braak, K. (2002). Haemocytic defence in black tiger shrimp (Penaeus monodon). Disertation. van Wangeningen University. Netherlands, 168 pp.

Verghese, B., Radhakrishnan, E.V., \& Padhi, A. (2007). Effect of environmental parameters on immune response of the Indian spiny lobster, Panulirus homarus (Linnaeus, 1758). Fish Shellfish Immunity, 23(5), 928-936.

Wang, H.C., Tseng, C.W., Lin, H.Y., Chen, I.T., Chen, Y.H., Chen, Y.M., Chen, T.Y., \& Yang, H.L. (2010). RNAi knock-down of the Litopenaeus vannamei Toll gene (LvToll) significantly increase mortality and reduces bacterial clearance alter challenge with Vibrio harveyi. Development and Comparative Immunology, 34, 49-58.

Zhou, X., Wang, Y., \& Li, W. (2009). Effect of probiotic on larvae shrimp (Penaeus vannamei) based on water quality, survival rate and digestive enzyme activities. Aquaculture, 287, 349-353.

Zokaeifar, H., Balcazar, J.L., Saad, C.R., Kamarudin, M.S., Sijam, K., Arshad, A., \& Nejat, N. (2012). Effects of Bacillus subtilis on the growth performance, digestive enzymes, immune gen expression and diseases resistance of white shrimp, Litopenaeus vannamei. Fish \& Shellfish Immunology, 33, 683-689. 